\title{
PENDIDIKAN ISLAM DAN PERKEMBANGAN PSIKOLOGI GENDER PADA PENYANDANG DISABILITAS HAMBATAN PENDENGARAN
}

\section{Solihin}

Sekolah Menengah Atas Luar Biasa (SMALB) Wiyata Dharma Metro

JL. Banteng, No. 22 A, Metro, Metro Pusat, Kota Metro, Lampung

Email: Solihin_bridge@yahoo.co.id

\begin{tabular}{|c|c|c|}
\hline Diterima: & Revisi: & Disetujui: \\
02 Oktober 2018 & 08 November 2018 & 20 Desember 2018 \\
\hline
\end{tabular}

\begin{abstract}
This paper describes Islamic education and the development of gender psychology in persons with hearing impairments. One aspect that supports the implementation of Islamic education is the aspect of psychology. Psychology studies can touch directly on the personality structure of students, so that it can facilitate the process of information transformation. The quality of one's gender intelligence depends on the process of growth and development psychologically. The religious and cultural values that develop in society also influence the psychological maturity of each gender. Hearing barriers are part of a separate problem in Islamic Education. Understanding this psychological condition is an important thing that must be done by everyone, especially educators because it is related to the development of the soul of deaf children. Psychological classification of deaf children who have been exposed above can facilitate learning that is carried out by educators, partially and in the context of the true purpose of Islamic education.
\end{abstract}

Keyword: Islamic education, disability, and psychology

\begin{abstract}
Abstrak
Tulisan ini mendeskripsikan tentang pendidikan Islam dan perkembangan psikologi gender pada penyandang disabilitas hambatan pendengaran. Salah satu aspek yang mendukung terlaksananya pendidikan Islam adalah aspek psikologi. Kajian psikologi dapat menyentuh langsung struktur kepribadian peserta didik, sehingga dapat memudahkan proses trasformasi ilmu pengetahuan. Kualitas kecerdasan gender seseorang tergantung dari proses pertumbuhan dan perkembangan secara psikologis. Nilai-nilai agama dan budaya yang berkembang di masyarakat turut pula memengaruhi kematangan psikologi setiap gender. Hambatan pendengaran menjadi bagian dari persoalan tersendiri dalam Pendidikan Islam. Memahami kondisi psikologis ini
\end{abstract}


menjadi hal penting yang harus dilakukan oleh setiap orang terutama pendidik karena berkaitan dengan perkembangan jiwa anak tunarungu. Klasifikasi psikologis terhadap anak tunarungu yang telah terpapar di atas dapat memudahkan pembelajaran yang di lakukan oleh pendidik, secara partisifatif dan dalam konteks tujuan pendidikan Islam yang sejatinya.

Kata Kunci: pendidikan Islam, disabilitas, dan psikologi

\section{A. Pendahuluan}

Pendidikan merupakan kebutuhan penting bagi setiap manusia, oleh karena itu harus selalu ditumbuhkembangkan secara sistematis oleh para pengambil kebijakan yang berwenang di Republik ini. Upaya perbaikan mutu pendidikan yang dilakukan oleh suatu bangsa selalu memiliki hubungan yang sangat signifikan dengan cita-cita Bangsa di masa mendatang, sebab pendidikan selalu di hadapkan pada perubahan pola hidup masyarakat. Pendidikan harus didesain mengikuti irama perubahan tersebut hingga menyentuh wilayah-wilayah yang paling dibutuhkan masyarakat.

Tuntutan pengembangan pendidikan menjadi suatu keharusan sesuai perkembangan jaman, tak terkecuali Pendidikan Islam, baik pada tataran konsep kurikulum, proses pembelajaran, fungsi, tujuan, menajemen lembaga-lembaga pendidikan serta sumber daya pengelola pendidikan. Selain itu ada pula beberapa aspek dalam mencapai tujuan seperti masalah psikologi pendidikan, materi pembelajaran, klasifikasi peserta didik, administrasi pendidikan, hingga evaluasi pendidikan. ${ }^{1}$ Semua ini menjadi sangat penting mengingat pendidikan Islam merupakan pandangan hidup bagi seorang Muslim.

Pendidikan Islam menurut Zarkowi Soejoeti, ada beberapa pengertian. Pertama, jenis pendidikan yang didirikan dan diselenggarakan atas dasar hasrat serta semangat cita-cita untuk mengejewantahkan nilai-nilai Islam, baik yang tercermin dalam nama lembaganya maupun dalam kegiatan-kegiatan yang diselenggara-

1 Zafar Alam, Islamic Education Theory \& Practice, (New Delhi: Adam Publishers and Distributors, 2003), h. 40 
kannya. Kedua, jenis pendidikan yang memberikan perhatian dan sekaligus menjadikan ajaran Islam sebagai pengetahuan untuk program studi yang diselenggarakannya. Di sini, kata Islam ditempatkan sebagai bidang studi, sebagai ilmu dan di perlakukan seperti ilmu yang lain. Ketiga, jenis pendidikan yang mencakup kedua pengertian di atas. Dalam hal ini, Islam di tempatkan sebagai bidang studi, sebagai sumber nilai dan sebagai bidang studi yang ditawarkan melalui program studi yang di selenggarakannya. ${ }^{2}$

Salah satu aspek yang mendukung terlaksananya pendidikan Islam adalah aspek psikologi. Sebab kajian psikologi dapat menyentuh langsung struktur kepribadian peserta didik, sehingga dapat memudahkan proses trasformasi ilmu pengetahuan. Sesungguhnya banyak disiplin keilmuan Islam yang mendasarkan pada teori psikologi. Dalam kajian pendidikan Islam misalnya, selama ini merujuk pada teori dan konsep psikologi perkembangan dan psikologi belajar dari psikologi konvensional (Barat). Sudah seharusnya teoriteori psikologi pendidikan Islam di dasarkan pula oleh psikologi kepribadian dalam konteks Islam meskipun masih sulit terlepas dari konsep-konsep psikologi barat.

Dalam proses perkembangan psikologi manusia, dari mulai buaian hingga renta tidak terlepas dari tahapan-tahapan secara kronologis dan mental yang kerap pula disebut sebagai umur biologis dan umur mental. Sehingga proses perkembangan kecerdasan seseorang dapat diukur melalui tes kecerdasan intelektual. IQ (Intelligence Quotient) seseorang di dapat dari usia mental seseorang di bagi usia kronologisnya kemudian dikalikan 100. Berikut rumusnya: $\mathrm{IQ}=\mathrm{MA} / \mathrm{CA} \times 100$. MA adalah mental age dan CA adalah chronological age. ${ }^{3}$

Gagasan pokok dalam perumusan rasio MA/CA adalah perbandingan relatif antara usia kronologis dengan usia mental yang

2 Ngainun Na'im \& Achmad Sauqi, Pendidikan Multikultural Konsep dan Aplikasi, (Yogyakarta; Ar-Ruzz Media Grup, 2010), h. 33.

3 Hadinarto, Psikologi dan Teori dan Pengukuran, (Bengkulu: Penerbit Rahman Rahim, 2009), h.76 
telah ditentukan berdasar rata-rata skor pada kelompok usia tersebut. Seorang yang berinteligensi normal, diharapkan pada usia lima tahun akan mencapai usia mental lima tahun, pada usia tujuh tahun akan mencapai usia mental tujuh tahun, dan seterusnya. Pembentukan umur kronologis dan mental tersebut terjadi pada setiap anak baik laki-laki maupun perempuan. Dan yang membedakan hanya pada pertumbuhan secara biologis.

Kualitas kecerdasan gender seseorang tergantung dari proses pertumbuhan dan perkembangan secara psikologis. Nilai-nilai agama dan budaya yang berkembang di masyarakat turut pula memengaruhi kematangan psikologi setiap gender. Meskipun dalam pertumbuhan seorang anak laki-laki lebih dominan memiliki kekuatan fisik di bandingkan anak perempuan. Namun, perkembangana mental gender bisa lebih dominan terjadi pada seorang perempuan, oleh karena itu meskipun memiliki perbedaan sudah barang tentu terdapat pula persamaan dalam sistem perkembangan secara etiologi.

\section{B. Pendidikan Islam: Konstruk Pendidikan Responsif Gender dan Psikologi Perkembangan}

Pendidikan dalam Islam lebih banyak dikenal dengan istilah al-tarbiyah, al-ta'lim, al-ta'dib dan al-riyadah. Setiap terminologi tersebut mempunyai makna yang berbeda satu sama lain, karena perbedaan teks dan kontek kalimatnya. Pendidikan Islam adalah usaha maksimal untuk menentukan kepribadian anak didik berdasarkan ketentuan-ketentuan yang telah digariskan dalam alQuran dan Sunnah. Usaha tersebut senantiasa harus di lakukan melalui bimbingan, asuhan dan didikan, dan sekaligus pengembangan potensi manusia untuk meningkatkan kualitas intelektual dan moral yang berpedoman pada syariat Islam.

Pendidikan Islam yang bersumber dari al-Quran dan alSunnah adalah landasan utama yang digunakan oleh para pengelola lembaga pendidikan Islam untuk mendapatkan konsep sebagai dasar pengembangan lembaga pendidikan. Dalam pendidikan Islam, ilmu yang dijabarkan dari teks suci disebut sebagai 'ulumuddin. 
Menurut Amin Abdullah, ketika disebut sebagai ulumuddin (religious knowledge), pemahaman kita umumnya langsung merujuk pada ilmu-ilmu agama (Islam) seperti Aqidah dan Syariah dengan menggunakan ilmu bantu bahasa dan logika deduktif yang merujuk pada menderivasi hukum-hukum, aturan-aturan, dan norma-norma dari kitab suci. Dari sana lalu muncul kluster ilmu-ilmu agama (Islam) seperti Kalam, Fikih, Tafsir, Hadis, Quran, Faraidl, Aqidah, Akhlak, Ibadah dan begitu seterusnya dengan ilmu bantu bahasa Arab. ${ }^{4}$

Dalam konteks Pendidikan Islam, penjabaran ulumuddin tersebut merupakan sebuah disiplin ilmu tersendiri yang berada dalam kurikulum pendidikan Islam. Bahkan dalam pendidikan reguler disipli-disiplin ilmu agama tersebut disederhanakan dalam sebuah kurikulum Pendidikan Agama Islam. Cakupan kurikulum menurut Abuddin Nata terdiri dari empat bagian, dua diantaranya ialah bagian yang berisi pengetahuan, informasi-informasi, data, aktifitas-aktifitas, dan pengalaman-pengalaman yang merupakan bahan bagi penyusunan kurikulum yang isinya berupa mata pelajaran yang kemudian dimasukkan dalam silabus. Berikutnya ialah bagian yang berisi metode atau cara menyampaikan mata pelajaran tersebut. ${ }^{5}$

Konstruksi ilmu Agama Islam yang diajarkan di sekolahsekolah reguler relatif minim, sementara isi kandungan ulumuddin yang sedemikian banyak tersebut harus terakomodir pada satu mata pelajaran Pendidikan Agama Islam. Hal ini menjadi problematika tersendiri yang sejatinya harus segera diselesaikan. Akibatnya, jika ilmu-ilmu Agama yang ada di dalam kurikulum pendidikan Islam kemudian disampaikan kepada peserta didik tanpa memiliki dasar keilmuan agama yang matang, dapat mengakibatkan masuknya nalarnalar emosional yang cenderung pada kepentingan-kepentingan pendidik/guru.

4 M. Amin Abdullah "Kata Pengantar", dalam Richard C Martin (ed), Pendekatan Terhadap Islam Dalam Studi Agama, (Yogyakarta: SukaPress, 2010), h. x

5 Abuddin Nata, Filsafat Pendidikan Islam, (Jakarta: Gaya Media Pratama, 2005), h. 177. 
Jika dikembalikan pada hakekat pendidikan Islam akan mencakup kehidupan manusia seutuhnya, oleh karena itu pendidikan Islam di sekolah reguler dengan beban waktu yang sedikit itu akan menjadi sangat efektif jika di fokuskan pada satu disiplin saja yaitu akhlak atau norma Agama Islam misalkan. Sementara bidang fiqih, akidah ,ilmu tafsir dan lain -lain bisa diajarkan di pendidikan diniyyah.

Pendidikan Islam merupakan sebuah proses pendekatan untuk membantu manusia mencapai kepada tingkat kesempurnaan yaitu manusia yang mencapai ketinggian iman dan ilmu, yang ditunjukkan dalam amal saleh, artinya proses pendidikan Islam harus diarahkan dalam sebagai pembangkit dan penggali potensi-potensi manusia. Serta mengurangi atau mengendalikan potensi negatif atau tidak berguna, sebab dalam diri manusia telah tercipta (terwujud) potensi berbuat baik dan berbuat jahat (negatif). ${ }^{6}$

Potensi-potensi dasar yang ada pada manusia menurut Gordon Willard Allport terdiri dari kepribadian, watak dan temperamen. ${ }^{7}$ Dalam proses pembelajaran dan pendidikan Islam, pendidik dapat mengarahkan sifat-sifat baik tersebut menjadi sebuah pembiasaan dalam setiap aktivitas peserta didik. Karena merubah tabiat menjadi watak dan lalu kepribadian tidaklah sesederhana membalikkan telapak tangan, perlu strategi yang tepat bagi masingmasing individu. Selain lingkungan pendidikan yang berusaha mengarah-bentuk watak peserta didik, pihak keluarga juga sangat berperan besar dalam mewujudkanya.

Dalam masyarakat, pola penentuan istilah gender (gender assignment) lebih banyak mengacu pada faktor biologis atau jenis kelamin. Peninjauan kembali istilah gender merupakan hal yang dipandang penting sebab dinilai mengandung unsur diskriminatif. Perlu identifikasi ulang istilah gender agar arus utama gender tidak sekadar pengenalan terhadap jenis kelamin, tetapi menyangkut pula nilai-nilai moral keagamaan, sosial dan budaya di dalam masyarakat.

${ }^{6}$ Jalaluddin Rahmad, Islam Alternatif, (Bandung: Mizan, 1991), h. 117.

7 Calvin S Hall dkk. Teori-Teori Sifat dan Behavioristik, (Jakarta: Kanisius, 1993), h.24 
Gender merupakan perbedaan antara laki-laki yang terlihat secara sosial, bukan hanya dilihat berdasarkan perbedaan biologis saja. Gender juga dapat diartikan sebagai sebuah peran sosial yang terbentuk dalam masyarakat. Dalam hal ini, Gender adalah perbedaan perilaku antara laki-laki dan perempuan bukan dilihat dari segi biologis, tetapi terbentuk melalui proses sosial dan budaya. Gender dapat berubah sedangkan jenis kelamin secara biologis akan tetap dan tidak berubah.

Selama ini istilah gender masih berkutat pada wilayah pembagian jenis kelamin yang ditentukan secara biologis. Misalkan seorang laki-laki adalah manusia yang memiliki alat kelamin penis, memproduksi sperma dan lain sebagainya. Sedangkan perempuan adalah manusia yang memiliki alat reproduksi sel telur, vagina, alat menyusui dan sebagainya. Alat-alat tersebut secara biologis melekat baik pada perempuan ataupun laki-laki. Fungsinya tidak dapat dipertukarkan dan secara permanen tidak berubah serta merupakan ketentuan biologis dari Tuhan (kodrat). ${ }^{8}$

Selain itu, konsep gender adalah pembagian antara laki-laki dan perempuan yang dikonstruksi secara sosial maupun kultural. Contohnya perempuan dianggap emosional, keibu-ibuan, lemah lembut dan lain sebagainya. Sedangkan laki-laki dianggap lebih kuat, perkasa, dan rasional. Sifat-sifat itu tidak selamanya akan seperti itu, karena sifat tersebut tidak abadi dan dapat dipertukarkan. Artinya ada seorang laki-laki yang emosional, lemah lembut, juga keibuan. Sementara itu, ada juga perempuan yang kuat, rasional, juga perkasa. Oleh karena itu, gender dari waktu ke waktu dapat berubah. ${ }^{9}$

Dalam konteks psikologi dan sosiologi peran gender tidak lagi digunakan dalam menempatkan posisi setara antara laki-laki dan perempuan untuk mewujudkan tatanan masyarakat sosial yang lebih

8 Mansuor Fakih, Analisis Gender dan Transformasi Sosial (Yogyakarta: pustaka pelajar, 1999), h. 7-8. Dalam jurnal Islam,"fenimisme dan konsep kesetaraan gender"., vol. 19 (2011), p. 107.

9 "Ibid, h.8-9". Dalam jurnal Islam, "Feminisme dan Konsep Kesetaraan Gender"., vol. 19 (2011). 
egaliter. Tidak pula sekadar perangkat operasional dalam melakukan pengukuran terhadap persoalan laki-laki dan perempuan terutama yang terkait dengan pembagian peran dalam masyarakat.

Gender membuka segala sekat diskriminasi baik perihal peran jenis kelamin, strata sosial kemasyarakatan serta perbedaan secara fisik dan mental. Dalam ruang ini penyandang disabilitas merupakan bagian dari struktur masyarakat yang turut pula memiliki berbagai hak-hak dan tanggungjawab dalam menjalankan kehidupan sosial.

Selanjutnya berkaitan dengan psikologi perkembangan. Psikologi perkembangan merupakan salah satu cabang dari psikologi khusus yang mempelajari perilaku dan perubahan perilaku individu dalam berbagai tahap perkembangan, mulai dari masa sebelum lahir (prenatal), masa bayi, masa kanak-kanak, masa anak kecil, masa anak sekolah dasar, masa remaja awal, masa remaja tengah dan adolesen, masa dewasa muda, dewasa dan dewasa tua, serta masa usia lanjut. Tiap tahap masa perkembangan tersebut menjadi obyek studi dari psikologi sebab setiap masa memiliki ciri-ciri atau karakteristik perkembangan yang berbeda.

Istilah perkembangan merujuk pada bagaimana orang tumbuh, menyesuaikan diri, dan berubah sepanjang perjalanan hidupnya melalui perkembangan fisik, perkembangan kepribadian, perkembangan sosioemosi, perkembangan kognisi (pemikiran), dan perkembangan bahasa. ${ }^{10} \mathrm{Jadi}$, perkembangan adalah pertumbuhan, penyesuaian, dan perubahan yang teratur dan berlangsung lama sepanjang perjalanan hidup. Teori tentang perkembangan manusia ada sangat banyak, diantaranya adalah teori perkembangan kognisi dan moral Jean Piaget, teori perkembangan kognisi Lev Vygotsky, teori perkembangan pribadi dan sosial Erik Erikson, serta teori perkembangan moral Lawrence Kohlberg.

Piaget, Vygotsky, Erikson, dan Kohlberg terpusat pada aspek perkembangan yang berbeda. Namun demikian, semua adalah pakar

10 Slavin Robert E., Psikologi Pendidikan Teori dan Praktik, (Jakarta: PT. Indeks, 2011), h .40 
teori tahap karena mereka sama-sama mempunyai keyakinan bahwa tahap-tahap perkembangan yang jelas dapat diidentifikasi dan di jelaskan. Namun, kesepakatan ini tidak berlanjut hingga ke penjelasan rinci teori mereka yang sangat berbeda jumlah tahap dan penjelasannya. Dan juga masing-masing pakar teori tersebut terpusat pada aspek perkembangan yang berbeda (misalnya kognisi, sosioemosi, kepribadian, moral). Istilah cognitive berasal dari kata cognition yang padanannya knowing, berarti mengetahui.

Dalam arti yang luas cognitive (kognisi) ialah perolehan, penataan, dan penggunaan pengetahuan. Dalam perkembangan selanjutnya, istilah kognitif menjadi popular sebagai salah satu domain atau wilayah/ranah psikologis manusia yang meliputi setiap perilaku mental yang berhubungan dengan pemahaman, pertimbangan, pengolahan informasi, pemecahan masalah, kesengajaan, dan keyakinan. Ranah kejiwaaan yang berpusat di otak ini juga berhubungan dengan konasi (kehendak) dan afeksi (perasaan) yang bertalian dengan ranah rasa. ${ }^{11}$ Jadi perkembangan kognisi adalah perubahan bertahap dan teratur yang menyebabkan proses mental menjadi semakin kompleks. Perkembangan dapat juga dikatakan sebagai suatu urutan-urutan perubahan yang bertahap dalam suatu pola yang teratur dan saling berhubungan. Perubahan-perubahan yang terjadi dalam perkembangan ini bersifat tetap, menuju ke suatu arah, yaitu ke suatu tingkat yang lebih tinggi.

Teori perkembangan kognitif Piaget adalah salah satu teori yang menjelaskan bagaimana anak beradaptasi dan menginterpretasikan dengan objek dan kejadian-kejadian sekitarnya. Bagaimana anak mempelajari ciri-ciri dan fungsi dari objek-objek seperti mainan, perabot, dan makanan serta objek-objek sosial seperti diri, orangtua, dan teman. Bagaimana cara anak mengelompokkan objek-objek untuk mengetahui persamaan-persamaan dan perbedaan-perbedaannya, untuk memahami penyebab terjadinya perubahan dalam objek-objek

11 Syah Muhibbin, Psikologi Belajar, (Jakarta: Rajawali Pers, 2012), h. 22 
dan perisiwa-peristiwa dan untuk membentuk perkiraan tentang objek-objek dan peristiwa tersebut.12

Jean Piaget adalah seorang pakar psikologi perkembangan yang paling berpengaruh dalam sejarah psikologi. Lahir di Swiss tahun 1896-1980. Setelah memperoleh gelar doktornya dalam biologi, dia menjadi lebih tertarik pada psikologi, dengan mendasarkan teoriteorinya yang paling awal pada pengamatan yang seksama terhadap ketiga anaknya sendiri. Piaget menganggap dirinya menerapkan prinsip dan metode biologi pada studi perkembangan manusia, dan banyak istilah yang dia perkenalkan pada psikologi diambil langsung dari biologi.13

Piaget mempelajari mengapa dan bagaimana kemampuan mental berubah lama-kelamaan. Bagi Piaget, perkembangan bergantung sebagian besar pada manipulasi anak terhadap interaksi aktifnya dengan lingkungan. Dalam pandangan Piaget, pengetahuan berasal dari tindakan. Teori perkembangan kognisi Piaget menyatakan bahwa kecerdasan atau kemampuan kognisi anak mengalami kemajuan melalui empat tahap yang jelas. Masing-masing tahap dicirikan oleh munculnya kemampuan dan cara mengolah informasi baru. Banyak di antara pokok teori Piaget ditantang oleh sejumlah riset di kemudian hari. Khususnya, banyak perubahan fungsi kognisi yang dia jelaskan kini diketahui berlangsung lebih dini, dalam lingkungan tertentu. Namun demikian, karya Piaget menjadi dasar penting untuk memahami perkembangan anak.

Teorinya memberikan banyak konsep utama dalam lapangan psikologi perkembangan dan berpengaruh terhadap perkembangan konsep kecerdasan, yang bagi Piaget berarti kemampuan untuk lebih tepat merepresentasikan dunia dan melakukan operasi logis dalam representasi konsep yang berdasar pada kenyataan. Teori ini membahas munculnya dan diperolehnya schemata yaitu pola mental yang menuntun perilaku, skema tentang bagaimana seseorang piaget/

12 http://prezi.com/uepcgwoue5_m/teori-perkembangan-kognitif-jean-

${ }^{13}$ Slavin Robert E., Psikologi Pendidikan Teori dan Praktik..., h .42 
mempersepsi lingkungannya dalam tahapan-tahapan perkembangan saat seseorang memperoleh cara baru dalam merepresentasikan informasi secara mental. ${ }^{14}$ Skema Piaget percaya bahwa semua anak dilahirkan dengan kecendrungan bawaaan untuk berinteraksi dengan lingkungan untuk memahaminya.

Teori Piaget merupakan akar revolusi kognitif saat ini yang menekankan pada proses mental. Piaget mengambil perspektif organismik yang memandang perkembangan kognitif sebagai produk usaha anak untuk memahami dan bertindak dalam dunia mereka. Menurut Piaget, bahwa perkembangan kognitif dimulai dengan kemampuan bawaan untuk beradaptasi dengan lingkungan.

Selain konsep kognitif piaget yang didasarkan pada perkembangan secara mental, terdapat pula kognisi sosial yang dapat diartikan sebagai pengetahuan tentang lingkungan sosial dan hubungan interpersonal. Model ini menyatakan tentang dampak atau pengaruh pengalaman sosial terhadap perkembangan kognitif. Teori ini menekankan tentang kebudayaan sebagai faktor penentu bagi perkembangan individu. Diyakaini, bahwa hanya manusia yang dapat menciptakan kebudayaan, dan setiap anak manusia berkembang dalam konteks kebudayaannya. Kebudayaan memberikan dua kontribusi terhadap perkembangan intelektual anak. Pertama, anak memperoleh banyak sisi pemahamannya. Kedua, anak memperoleh banyak cara berpikir, atau alat-alat adaptasi intelektual. ${ }^{15}$

Vygotsky tidak setuju dengan pandangan Piaget bahwa anak menjelajahi dunianya sendiri dan membentuk gambaran realitas batinnya sendiri. Vygotsky menekankan bagaimana proses-proses perkembangan mental seperti ingatan, perhatian, dan penalaran melibatkan pembelajaran menggunakan temuan-temuan masyarakat seperti bahasa, sistem matematika, dan alat-alat ingatan.

Penekanan Vygotsky pada peran kebudayaan dan masyarakat di dalam perkembangan kognitif lebih banyak menekankan peranan

\footnotetext{
14 http://id.wikipedia.org/wiki/Teori_perkembangan_kognitif

15 Syamsu Yusuf, Psikologi perkembangan anak \& remaja, (Bandung, Remaja Rosdakarya, 2010), h.7
} 
orang dewasa dan anak-anak lain dalam memudahkan perkembangan si anak. Menurut Vygotsky, anak-anak lahir dengan fungsi mental yang relatif dasar seperti kemampuan untuk memahami dunia luar dan memusatkan perhatian. Namun, anak-anak tak banyak memiliki fungsi mental yang lebih tinggi seperti ingatan, berfikir dan menyelesaikan masalah. Pada intinya dapat disimpulkan bahwa dalam teori Vygotsky mengandung banyak unsur psikologi pendidikan, khususnya pokok bahasan pendidikan dan budaya.

Seperti Piaget, Vygotsky menekankan bahwa anak-anak secara aktif menyusun pengetahuan mereka. Akan tetapi menurut Vygotsky, fungsi-fungsi mental memiliki koneksi-koneksi sosial. Vygotsky berpendapat bahwa anak-anak mengembangkan konsep-konsep lebih sistematis, logis, dan rasional sebagai akibat dari percakapan dengan seorang penolong yang ahli.

Menurut Vygotsky, perolehan pengetahuan dan perkembangan kognitif seorang seturut dengan teori sciogenesis. Dimensi kesadaran sosial bersifat primer, sedangkan dimensi individualnya bersifat derivatif atau merupakan turunan dan bersifat skunder. Artinya, pengetahuan dan pengembangan kognitif individu berasal dari sumber-sumber social di luar dirinya. Hal ini tidak berarti bahwa individu bersikap pasif dalam perkembangan kognitifnya, tetapi Vygotsky juga menekankan pentingnya peran aktif seseorang dalam mengkonstruksi pengetahuannya. Maka teori Vygotsky sebenarnya lebih tepat disebut dengan pendekatan konstruktivisme. Maksudnya, perkembangan kognitif seseorang disamping ditentukan oleh individu sendiri secara aktif, juga oleh lingkungan sosial yang aktif pula.

Teori psikologi yang dipegang oleh vygotsky lebih mengacu pada kontruktivisme. Karena ia lebih menekan pada hakikat pembelajaran sosiokultural. Dalam analisisnya, perkembangan kognitif seseorang disamping ditentukan oleh individu sendiri secara aktif, juga ditentukan oleh lingkungan social secara aktif.16 vygotsky.html

16 http://aniqiyah09luluk.blogspot.com/2012/12/teori-perkembangan- 
Kognitif manusia sebagai suatu sistem yang terdiri atas tiga bagian: 1) Input, yaitu proses informasi dari lingkungan atau stimulasi (rangsangan) yang masuk ke dalam reseptor-reseptor pancaindera dalam bentuk penglihatan, suara, dan rasa; 2) Proses, yaitu pekerjaan otak untuk mentransformasikan informasi atau stimulasi dalam cara yang beragam, yang meliputi mengolah/menyusun informasi ke dalam bentuk-bentuk simbolik, membandingkan dengan informasi sebelumnya, memasukan ke dalam memori dan menggunakannya apabila diperlukan. 3) Output, yaitu yang berbentuk tingkah laku, seperti berbicara, menulis, interaksi sosial, dan sebagainya. ${ }^{17}$

Vygotsky berkeyakinan bahwa perkembangan tergantung baik pada faktor biologis menentukan fungsi-fungsi elementer memorie, atensi, persepsi, dan stimulus respon, faktor sosial sangat penting artinya bagi perkembangan fungsi mental lebih tinggi untuk pengembangan konsep, penalaran logis, dan pengambilan keputusan, teori Vygotsky ini, lebih menekankan pada aspek sosial dari pembelajaran. ${ }^{18}$

Dan ini sejalan dengan teori konvergensi yang dipelopori oleh Wlliam Stern, Ia berpedapat bahwa seorang anak dilahirkan di dumia sudah disertai pembawaan baik maupun pembawaan buruk. Proses perkembangan anak, baik faktor pembawaan maupun faktor lingkungan sama sama mempunyai peranan sangat penting. Bakat yang dibawa pada waktu lahir tidak akan berkembang dengan baik tanpa adanya dukungan lingkungan sesuai untuk perkembangan anak itu. ${ }^{19}$

Singkatnya, kebudayaan telah mengajari anak tentang apa yang dipikir dan bagaimana cara berpikir. Vygotsky meyakini bahwa perkembangan kognitif menghasilkan proses sosial intruksional, yang karenanya anak belajar saling tukar pengalaman dalam memecahkan

\footnotetext{
17 Syamsu Yusuf, Psikologi perkembangan...h.7

18 Singgih D. Gunarsa, Dari Anak Sampai Usia Lanjut, (Jakarta: Gunung Mulia: 2004), h.75 pendidikan/

19 http://fatamorghana.wordpress.com/2008/07/20/bab-vi-aliran-aliran-
} 
masalah dengan orang lain, seperti orang tua, guru saudara, dan teman sebaya. Perkembangan merupakan proses internalisasi terhadap kebudayaan yang membentuk pengetahuannya dan alat adaptasi yang wahana utamanya melalui bahasa dan komunikasi verbal.

Selain Vygotsky, salah satu ahli yang mendasari teorinya dari sudut sosial ialah Erikson dengan menyebut pendekatannya "Psikososial" atau "Psikohistoris". Ia berusaha menjelaskan bahwa ada hubungan timbal balik antara pribadi dan kebudayaan sampai orang tersebut menjadi dewasa. Disini terlihat bahwa lingkungan hidup seseorang dari awal sampai akhir dipengaruhi oleh sejarah seluruh masyarakat karena perkembangan relasi antara sesama manusia, masyarakat serta kebudayaan semua saling terkait. Itu berarti tiap individu punya kesanggupan untuk menyesuaikan diri dengan lingkungan yang senantiasa berkembang dari orang-orang atau institusi supaya ia bisa menjadi bagian dari perhatian kebudayaan secara terus-menerus.

Erikson berusaha menemukan perkembangan psikososial ego melalui berbagai organisasi sosial dalam kelompok atau kebudayaan tertentu. Ia mencoba meletakkan hubungan antara gejala psikis, edukatif dan gejala budaya masyarakat. Dalam penelitiannya, Erikson membuktikan bahwa masyarakat atau budaya melalui kebiasaan mengasuh anak, struktur keluarga tertentu, kelompok sosial maupun susunan institusional, membantu perkembangan anak dalam berbagai macam daya ego yang diperlukan untuk menerima berbagai peran serta tanggung jawab sosial.

Erikson berpendapat bahwa setiap anak memiliki jadwal waktunya sendiri, karena itu akan menyesatkan kalau ditentukan lama berlangsungnya secara eksak masing-masing untuk setiap tahap. ${ }^{20}$ Artinya bahwa setiap tahap tidak dilewati lalu ditinggalkan,

${ }^{20}$ Calvin S Hall dkk. Teori-Teori Psikodinamik, (Klinis), (Jakarta: Kanisius, 1993), h. 141 
namun masing-masing tahap dalam setiap interaksi sosial ikut serta dalam membentuk seluruh kepribadian.

\section{Pendidikan Islam Bagi Penyandang Tunarungu}

Amanat hak atas pendidikan bagi penyandang kelainan atau ketunaan ditetapkan dalam Undang-Undang No. 20 Tahun 2003 tentang Sisdiknas Pasal 32 disebutkan bahwa: "pendidikan khusus (pendidikan luar biasa) merupakan pendidikan bagi peserta didik yang memiliki tingkat kesulitan dalam mengikuti proses pembelajaran karena kelainan fisik, emosional, mental, sosial". Ketetapan dalam UU No. 20 Tahun 2003 tersebut bagi anak penyandang kelainan sangat berarti karena memberi landasan yang kuat bahwa anak berkelainan perlu memperoleh kesempatan yang sama sebagaimana yang diberikan kepada anak normal lainnya dalam hal pendidikan dan pengajaran.

Banyak sekali istilah-istilah yang digunakan bagi orang yang memiliki berbagai hambatan secara fisik maupun mental. Namun pada tahun 2016 istilah difabel, berkelainan, penyandang cacat, telah disepakati secara regulatif menggunakan penyandang disabilitas. Sebagaimana dijelaskan dalam UU No. 08 Tahun 2016 pasal 1 yaitu setiap orang yang mengalami keterbatasan fisik, intelektual, mental, dan/atau sensorik dalam jangka waktu lama yang dalam berinteraksi dengan lingkungan dapat mengalami hambatan dan kesulitan untuk berpartisipasi secara penuh dan efektif dengan warga negara lainnya berdasarkan kesamaan hak.

Dengan memberikan kesempatan yang sama kepada penyandang disabilitas untuk memperoleh pendidikan dan pengajaran, berarti memperkecil kesenjangan angka partisipasi pendidian anak berkebutuhan khusus. Untuk investasi jangka panjang dengan lahirnya para penyandang cacat yang terdidik dan terampil, secara tidak langsung dapat mengurangi biaya pos perawatan dan pelayanan 
kebutuhan sehari-hari.21 Di samping itu ada efek psikologis, yaitu tumbuhnya motif berprestasi dan meningkatnya harga diri anak berkelainan, yang nilainya jauh lebih penting dan dapat melebihi nilai ekonomi. Kondisi yang konstruktif ini dapat memperkuat pembentukan konsep diri anak berkelainan.

Dalam pendidikan Islam, terdapat dua hal yang sangat penting untuk menjadi dasar sebuah kurikulum. Ada dua keyword dalam pendidikan Islam, yaitu pembelajaran dan pendidikan. Pembelajaran diartikan sebagai proses, perbuatan, cara mengajar, atau mengajarkan sehingga anak didik mau belajar. ${ }^{22}$ Sementara itu, pendidikan merupakan suatu usaha bimbingan dan asuhan terhadap anak didik agar nanti setelah selesai dari pendidikan dapat memahami apa yang terkandung di dalam Islam secara keseluruhan, menghayati makna dan maksud serta tujuannya dan pada akhirnya dapat mengamalkannya serta menjadikan ajaran-ajaran agama Islam yang telah dianutnya itu sebagai pandangan hidupnya sehingga dapat mendatangkan keselamatan dunia dan akhiratnya kelak. ${ }^{23}$

Jadi, pembelajaran agama Islam merupakan proses belajar mengajar terhadap anak didik tentang ajaran agama Islam agar peserta didik memahami, menghayati berbagai ilmu keagamaan.

Mengingat penyandang tunarungu memiliki hambatan pendengaran yang menyebabkan ketidakmampuan berbahasa lisan dengan baik, serta lemahnya aktivitas menyimaknya maka cukup wajar jika perkembangan intelegensi tidak sesuai dengan proses perkembangan pada umumnya. Hambatan tersebut secara pasti telah menimbulkan permasalahan dalam proses transformasi pengetahuan tentang berbagai disiplin keilmuan tak terkecuali pendidikan Islam.

Secara khusus memang belum banyak pembahasanpembahasan tentang pendidikan Islam bagi tunarungu, baik dalam bidang fiqih, tauhid, nahwu sharaf dan lain sebagainya. Misalkan

${ }^{21}$ Mohammad effendi, Pengantar Psikopedagogik Anak Berkelainan, (Jakarta, PT Bumi Aksara, 2006), h. 1

22 Susanto. Teori Belajar di Sekolah Dasar, (Jakarta: Kencana, 2013), h.18-19

23 Darajat, dkk. Ilmu Pendidikan Islam, (Jakarta: Bumi Aksara, 2011), h. 88 
adapun, pembahasannya terfokus pada wilayah jenis kelamin antara laki-laki dan perempuan, anak-anak maupun dewasa.

Namun, mengingat kondisi psikologis penyandang tunarungu baik pertumbuhan secara biologis maupun perkembangan mental. Serta mempertimbangkan pula perkembangan bahasa, perkembangan prilaku dan perkembangan sosial di masyarakat maka, terdapat berbagai keringanan-keringanan secara hukum fiqhiyyah dan maupun norma-norma akhlak. Atau permakluman terhadap ketidaktepatan melafalkan huruf-huruf Arab (al-Quran) dalam pembelajaran ilmu tajwid. Hal ini semata-mata untuk memberikan peluang yang terbuka dan lebih baik kepada seluruh penyandang tunarungu agar tidak terlalu jauh melenceng dalam menangkap dan memahami ilmu-ilmu pendidikan agama Islam.

Selanjutnya, pemberdayaan anak didik penyandang kelainan memerlukan pemahaman psikologi tersendiri, hal ini dikarnakan anak-anak yang berkelainan memiliki kompleksitas dalam berbagai hal. Karna setiap klasifikasi anak tersebut membutuhkan perangkat pendidikan yang berbeda, yang terdiri dari model dan strategi pembelajaran hingga evaluasi khusus.

1. Anak Tuna Rungu dan Klasifikasinya

Tunarungu dapat diartikan sebagai suatu keadaan kehilangan pendengaran yang mengakibatkan seseorang tidak dapat menangkap berbagai rangsangan, terutama melalui indera pendengarannya. Batasan pengertian anak tunarungu telah banyak dikemukakan oeh para ahi yang semuanya itu pada dasarnya mengandung pengertian yang sama. Di bawah ini dikemukakan beberapa definisi anak tunarungu.

Andreas Dwidjosumarto mengemukakan bahwa seseorang yang tidak atau kurang mampu mendengar suara dikatakan tunarungu. Ketunarunguan dibedakan menjadi dua kategori yaltu tuli (deaf) dan kurang dengar (low of hearing). Tuli adalah mereka yang indera pendengarannya mengalami kerusakan dalam taraf berat sehingga pendengaran tidak berfungsi lagi. Sedangkan kurang dengar adalah mereka yang indera pendengarannya 
mengalami kerusakan tetapi masih dapat berfungsi untuk mendengar, baik dengan maupun tanpa menggunakan alat bantu dengar (hearing aids). ${ }^{24}$

Selain itu, Mufti Salim menyimpulkan bahwa anak tunarungu adalah anak yang mengalami kekurangan atau kehilangan kemampuan mendengar yang disebabkan oleh kerusakan atau tidak berfungsinya sebagian atau seluruh alat pendengaran sehingga mengalami hambatan dalam perkembangan bahasanya. Ia memerlukan bimbingan dan pendidikan khusus untuk mencapai kehidupan lahir batin yang layak..$^{25}$

Memperhatikan batasan-batasan di atas, dapatlah ditarik kesimpulan bahwa tunarungu adalah mereka yang kehilangan pendengaran baik sebagian (hard of hearing) maupun seluruhnya (deat) yang menyebabkan pendengarannya tidak memiliki nilai fungsional di dalam kehidupan sehari-hari.

Berdasarkan pada hal tersebut, maka dapat diklasifikasikan jenis-jenis tuna rungu, yakni:

a. Klasifikasi secara etiologis, yaitu pembagian berdasarkan sebab-sebab, dalam hal penyebab ketunarunguan ada beberapa faktor, yaitu:

(1) Pada saat sebelum dilahirkan, hal ini meliputi: (a) Salah satu atau kedua orang tua anak menderita tuna rungu atau mempunyai gen sel pembawa sifat abnormal, misalnya dominat genes, recesive gen, dan lain-lain; (b) Karena penyakit; sewaktu ibu mengandung terserang suatu penyakit, terutama penyakit-penyakit yang diderita pada saat kehamilan di semester pertama yaitu pada saat pembentukan ruang telinga. Penyakit itu ialah rubella, moribili, dan lain-lain; (c) Karena keracunan obat-obatan; pada saat kehamilan, ibu meminum obat-obatan terlalu banyak, ibu seorang pecandu alkohol, atau ibu tidak

24 Sutjihati soemantri, Psikologi Anak Luar Biasa, cet.2, (Bandung,PT Rafika Aditama, 2007), h. 93

25 Sutjihati soemantri, Psikologi...h.94 
menghendaki kehadiran anaknya sehingga ia meminum obat penggugur kandungan, hal ini akan dapat menyebabkan ketunarunguan pada anak yang dilahirkan.

(2) Pada saat kelahiran, meliputi: (a) Sewaktu melahirkan, ibu mengalami kesulitan sehingga persalinan dibantu dengan penyedotan (tang); (b) Prematuritas, yakni bayi yang lahir sebelum waktunya.

(3) Pada saat setelah kelahiran (post natal), meliputi: (a) Ketulian yang terjadi karena infeksi, misalnya infeksi pada otak (meningitis) atau infeksi umum seperti difteri, morbili, dan lain-lain; (b) Pemakaian obat-obatan ototoksi pada anak-anak; (c) Karena kecelakaan yang mengakibatkan kerusakan alat pendenga bagian dalam, misalnya jatuh.

b. Klasifikasi menurut tarafnya, yakni klasifikasi berdasarkan dengan tes audiometris. Menurut Andreas Dwidjosumarto meliputi:

Tingkat I, Kehilangan kemampuan mendengar antara 35 sampai $54 \mathrm{~dB}$ (penderita hanya memerlukan latihan berbicara dan bantuan mendengar secara khusus.

Tingkat II, Kehilangan kemampuan mendengar antara 55 sampai $69 \mathrm{~dB}$ penderita kadang-kadang memerlukan penempatan sekolah secara khusus, dalam kebiasaan seharihari memerlukan latihan berbicara secara khusus.

Tingkat Ill, Kehilangan kemampuan mendengar antara 70 sampai $89 \mathrm{~dB}$.

Tingkat IV, Kehilangan kemampuan mendengar 90 dB ke atas.

Penderita pada tingkat I dan II dikatakan mengalami gangguan pendengaran dan masih terdapat sisa pendegaran. Mereka dapat melakukan latihan berbicara, mendengar mengguanakan alat bantu dengar. Adapun yang kehilangan kemampuan mendengar pada tingkat Ill dan IV pada hakekatnya memerlukan pelayanan pendidikan secara khusus. 
Perkembangan bahasa dan bicara berkaitan erat dengan ketajaman pendengaran. Akibat terbatasnya ketajaman pendengaran, anak tunarungu tidak mampu mendengar dengan baik. Dengan demikian pada anak tunarungu tidak terjadi proses peniruan suara setelah mas a meraban, proses peniruannya hanya sebatas visual.

\section{Perkembangan Kognitif Anak Tunarungu}

Pada umumnya inteligensi anak tunarungu secara potensial sama denga anak normal, tetapi secara fungsional perkembangannya dipengaruhi oleh tingkat kemampuan berbahasanya, keterbatasan informasi, dan daya abstraksi anak. Akibat ketunarunguannya menghambat proses pencapaia pengetahuan yang lebih luas. Dengan demikian perkembangan inteligen secara fungsional terhambat. Perkembangan kognitif anak tunarungu sangat dipengaruhi oleh perkembangan bahasa, sehingga hambatan pada bahasa akan rnenghambat perkembangan inteligensi anak tunarungu.

Kerendahan tingkat inteligensi anak tunarungu bukan berasal dai hambatan intelektualnya yang rendah melainkan secara umum karen inteligensinya tidak mendapat kesempatan untuk berkembang. Pemberian bimbingan yang teratur terutama dalam kecakapan berbahasa akan dapat membantu perkembangan inteligensi anak tunarungu. Tidak semua aspek inteligensi anak tunarungu terhambat. Aspek inteligensi yang terhambat perkembangannya ialah yang bersifat verbal, misalnya merumuskan pengertiai menghubungkan, menanik kesimpulan, dan meramalkan kejadian.

Aspek inteligensi yang bersumber dan penglihatan dan yang berupa motorik tidak banyak mengalami hambatan tetapi justru berkembangnya lebih cepat. Cruickshank yang dikutip leh Yuke R. Siregar mengemukakan bahwa anak-anak tunarungu sering memperlihatkan keterlambatan dalan belajar dan kadang-kadang tampak terbelakang. ${ }^{26}$ Keadaan ini tidak hanya disebabkan oleh

${ }^{26}$ Sutjihati soemantri, Psikologi...h. 97 
derajat gangguan pendengaran yang dialami anak tetap juga tergantung pada potensi kecerdasan yang dimiliki, rangsangan mental serta dorongan dan lingkungan luar yang memberikan kesempatan bagi anak untuk mengembangkan kecerdasan itu.

\section{Perkembangan Emosi Anak Tunarugu}

Kekurangan akan pemahaman bahasa lisan atau tulisan seringkali menyebabkan anak tunarungu menafsirkan sesuatu secara negatif atau salah dan ini sering menjadi tekanan bagi emosinya, yang dapat menghambat perkembangan pribadinya dengan menampilkan sikap menutup diri, bertindak agresif, atau sebaliknya menampakkan kebimbangan dan keragu-raguan.

Emosi anak tunarungu selalu bergolak di satu pihak karena kemiskinan bahasanya dan di pihak lain karena pengaruh dari luar yang diterimanya. Anak tunarungu bila ditegur oleh orang yang tidak dikenalnya akan tampak resah dan gelisah. Rasa khawatir yang menjelma dalam perasaan keragu-raguan dan sikap putus asa dapat diberantas berbagai variasi misalnya latihan, pesta, dan lain-lain yang dilakukan secara berbeda. ${ }^{27}$

\section{Perkembangan Sosial Anak Tunarungu}

Manusia sebagai makhluk sosial selalu memerlukan kebersamaan dengan orang lain. Demikian pula anak tunarungu, ia tidak terlepas dari kebutuhan tersebut. Akan tetapi karena mereka memiliki kelainan dalam segi fisik, biasanya akan menyebabkan suatu kelainan dalam penyesuaian diri terhadap lingkungan. Pada umumnya lingkungan melihat mereka sebagai individu yang memiliki kekurangan dan menilainya sebagai seseorang yang kurang berkarya. Dengan penilaian lingkungan yang demikian, anak tunarungu merasa benar-benar kurang berharga. Dengan penilaian dan lingkungan yang demikian juga memberikan pengaruh yang benar-benar besar terhadap perkembangai fungsi sosialnya. Dengan adanya hambatan

27 Lani gunawan et al. Penguasaan bahasa anak tunarungu, (Jakarta: Yayasan Santi Rama, 2000), h.31 
dalam perkembangan sosial ini mengakibatkan pula minimalnya penguasaan bahasa dan kecenderungan menyendiri serta memiliki sifat egosetris.

Faktor sosial dan budaya meliputi pengertian yang sangat luas, yaitu lingkungan hidup di mana anak berinteraksi. Interaksi antara individu dengan kelompok, keluarga, dan masyarakat. Untuk kepentingan anak tunarungu, seluruh anggota keluarga, guru, dan masyarak di sekitarnya hendaknya berusaha mempelajari dan memahami keadaan mereka karena hal tersebut dapat menghambat perkembangan kepribadi yang negatif pada diri anak tunarungu.

Kita harus berhati-hati jika ada pendapat bahwa ketunaan seperti tunarungu biasanya mengakibatkan kelainan dalam penyesuaian diri terhadap lingkungannya. Kalaupun terjadi, hal itu bukanlah sebagai akibat dari kelainannya itu semata. Sebab kelainan fisik hanyalah merupakan variasi dalam kelainan psikologis. Jadi bukanlah reaksi langsung, melainkan hanya akibat reaksi anak dan lingkungannya tidak memahami keadaan.

Anak tunarungu banyak dihinggapi kecemasan karena menghadapi Iingkungan yang beraneka ragam, hal seperti ini aka membingungkan anak tunarungu. Anak tunarungu sering mengalami berbagai konflik, kebingungan, dan ketakutan karena ia sebenarnya hidup dalam Iingkungan yang bermacam-macam.

\section{Perkembangan Perilaku Anak Tunarungu}

Kepribadian pada dasarnya merupakan keseluruhan sifat dan sikap pada seseorang yang menentukan cara-cara yang unik dalam penyesuaiannya dengan lingkungan. Oleh karena itu banyak ahli berpendapat perlu diperhatikannya masalah penyesuaian seseorang agar kita mengetahui bagaimana kepribadiannya. Demikian pula anak tunarungu, untuk mengetahui keadaan kepribadiannya, perlu kita perhatikan bagaimana penyesuaian diri mereka.

Perkembangan kepribadian banyak ditentukan oleh hubungan antara anak dan orang tua terutama ibunya. Lebih-lebih pada masa awal perkembangannya. Perkembangan kepribadian terjadi dalam 
pergaulan atau perluasan pengalaman pada umumnya dan di arahkan pada faktor anak sendiri. Pertemuan antara faktor-faktor dalam diri anak tunarungu, yaitu ketidakmampuan menerima rangsang pendengaran, kemiskinan berbahasa, ketidaktetapan emosi, dan keterbatasan inteligensi dihubungkan dengan sikap lingkungan terhadapnya dalam menghambat perkembangan kepribadiannya.

\section{Kesimpulan}

Berdasarkan pada penjelasan dan uraian di atas dapat disimpulkan bahwa hambatan pendengaran adalah bagian dari persoalan tersendiri dalam Pendidikan Islam sebab masih kerap terjadi dalam sebuah kehidupan di masyarakat. Sehingga memahami kondisi psikologis tersebut sebagai hal yang harus dilakukan oleh setiap orang terutama pendidik karena berkaitan dengan perkembangan jiwa anak tunarungu. Klasifikasi psikologis terhadap anak tunarungu yang telah terpapar di atas dapat memudahkan pembelajaran yang di lakukan oleh pendidik, secara partisifatif dan dalam konteks tujuan pendidikan Islam dan untuk memanusiakan manusia.[]

\section{Daftar Pustaka}

Abdullah. M. Amin, "Kata Pengantar", dalam Richard C Martin (ed), Pendekatan Terhadap Islam Dalam Studi Agama Yogyakarta: SukaPress, 2010.

Alam. Zafar, Islamic Education Theory \& Practice, New Delhi: Adam Publishers and Distributors, 2003.

Darajat, dkk., Ilmu Pendidikan Islam, Jakarta: Bumi Aksara, 2011.

Effendi. Mohammad, Pengantar Psikopedagogik Anak Berkelainan, Jakarta, PT Bumi Aksara, 2006.

Fakih. Mansuor, Analisis Gender dan Transformasi Sosial, Yogyakarta: Pustaka Pelajar, 1999. 
Gunarsa, Singgih.D. Dari Anak Sampai Usia Lanjut, Jakarta: Gunung Mulia, 2004.

Gunawan. Lani, et al., Penguasaan bahasa anak tunarungu, Yayasan Santi Rama, Jakarta, 2000.

Hadinarto, Psikologi dan Teori dan Pengukuran, Bengkulu: Penerbit Rahman Rahim, 2009.

Hall, Calvin S. dkk. Teori-Teori Sifat dan Behavioristik, Jakarta: Kanisius, 1993. Teori-Teori Psikodinamik, (Klinis), Jakarta: Kanisius, 2011

http://aniqiyah09luluk.blogspot.com/2012/12/teori-perkembanganvygotsky.html

http://fatamorghana.wordpress.com/2008/07/20/bab-vi-aliranaliran-pendidikan/

http://id.wikipedia.org/wiki/Teori_perkembangan_kognitif.

http://prezi.com/uepcgwoue5 m/teori-perkembangan-kognitif-jeanpiaget/

Muhibbin. Syah, Psikologi Belajar, Jakarta: Rajawali Pers, 2012.

Na'im. Ngainun, \& Achmad Sauqi., Pendidikan Multikultural Konsep dan Aplikasi, Yogyakarta; Ar-Ruzz Media Grup, 2010

Nata, Abuddin. Filsafat Pendidikan Islam, (Jakarta: Gaya Media Pratama, 2005

Rahmad. Jalaluddin, Islam Alternatif, Bandung: Mizan, 1991.

Slavin. Robert E. Psikologi Pendidikan Teori dan Praktik, Jakarta: PT.Indeks, 2011.

Soemantri. Sutjihati, Psikologi Anak Luar Biasa, Bandung: PT Rafika Aditama, 2007. 
Susanto, Teori Belajar di Sekolah Dasar, Jakarta: Kencana, 2013.

Yusuf. Syamsu, Psikologi perkembangan anak \& remaja, Bandung, Remaja Rosdakarya, 2010. 